\title{
14. BUILDING BRIDGES - LAW AND JUSTICE REFORM IN PAPUA NEW GUINEA
}

By: Sinclair Dinnen

\section{KEY TERMS AND PHRASES}

\section{Governance}

The manner in which power is exercised (in a country, community or any other organisation) for the management of social and economic resources.

\section{Kiap}

The Melanesian pidgin term used to describe patrol and district officers in colonial Papua and New Guinea.

\section{Polity}

According to the Oxford dictionary this is the term for a form or process of civil government, a condition of civil order. Here it is used to refer to a particular political order, whether of a village, tribe, island or nation. 


\section{INTRODUCTION}

Problems of lawlessness loom large in current accounts of Papua New Guinea. Concerns about these problems have induced high levels of personal insecurity, as well as providing a major disincentive to foreign investment. While such problems cannot be resolved by law and justice solutions alone, the continuing deterioration of PNG's 'law and order'1 situation raises questions about the adequacy of the formal regulatory system. Successive governments have been loud with 'tough' rhetoric, like many of their counterparts elsewhere. Practical responses have been essentially reactive and short term. ${ }^{2}$ Australia, PNG's largest aid donor, has claimed to concentrate on institutional strengthening projects with individual law and justice agencies. While there have been achievements it is clear that improving the performance of law and justice processes is a complex and long term task and one that needs to be integrated with other areas of governance reform.

Building a more effective law and justice sector requires strategies that go beyond the strengthening of particular institutions. Given the operational interdependence of law and justice agencies, a broader sectoral focus is needed. In addition, while the state is the central player, there is a need to recognise the contributions of other stakeholders to the management of conflict and maintenance of peace at local levels. PNG's nongovernment sector, comprising 'traditional' structures of governance, community groups, churches, NGOs and the private sector, already plays a significant, if often unacknowledged, role. A sustainable law and justice framework needs to delineate responsibilities between different organisations and develop appropriate and mutually reinforcing linkages between government and non-government sectors.

This chapter examines the challenges facing PNG's law and justice sector and identifies key directions for reform. Section one describes the broader context of PNG's problems of order, including the acute fragility of the nation-state and the high levels of social and legal pluralism. Attention is drawn to the restorative character of many 'traditional' justice practices and the manner of their interactions with colonial institutions of social control. Section two examines the workings of the modern criminal justice system. Its shortcomings are attributed as much to a lack of legitimacy and strong social foundations as to its patent lack of institutional capacity. The final section looks at the recently endorsed National Law and Justice Policy and Plan of Action and the prospects for building a more socially attuned and effective law and justice system.

\section{THE CONTEXT OF CHANGE}

The broader context is one of rapid change induced by a combination of local and global forces that have left few individuals or communities untouched. PNG was granted independence in 1975 after a relatively short and uneven period of colonial administration. Over 800 languages are spoken among a population of just over five million people scattered across the eastern half of the island of New Guinea. The institutions and traditions of small, self-regulating societies have demonstrated 
remarkable resilience and adaptability in the face of colonial and post-colonial change. Twenty-seven years after independence, the primary allegiances and identities of most Papua New Guineans remain firmly implanted in local kin-based associations.

Building the institutional framework of modern statehood, including a uniform system of law and justice, commenced in earnest during an intensive period of institutional modernisation in the twenty years preceding Independence. As in other parts of Melanesia, the birth of the new 'nation' occurred in the absence of any shared sense of identity among its 'citizens'. Binding so many disparate communities into an effective political and ideological unit remains a formidable challenge. ${ }^{3}$

Despite the many gloomy forecasts, Papua New Guinea has stayed intact and retains an impressive record of uninterrupted democratic government. Serious challenges nevertheless remain, many of these stemming from the fragility of the post-colonial nation-state. The tragic and costly 12-year Bougainville war provides the most dramatic example. A weak national economy is hostage to the vagaries of regional and international markets. Levels of debt have risen as successive governments have been forced to seek loans from the multilateral development banks and bilateral donors. Economic mismanagement has contributed to growing popular discontent. Social indicators suggest a serious reversal of early advances, particularly in the areas of health and education. On a global scale, PNG's human development profile ranks in the lower one-third of all nations and is the lowest of all the Pacific island countries. ${ }^{4}$ Government services are in a perilous state in many rural areas, where over $85 \%$ of the population live. Whilst the reformist government of Sir Mekere Morauta struggles to reverse this pattern of decline, political instability, corruption and lawlessness continue to pose a major threat.

\section{CRIME AND LAWLESSNESS}

The most visible manifestation of PNG's 'law and order' problems is the growth of so-called raskol crime in the main urban centres. ${ }^{5}$ Serious outbreaks of inter-group conflict have also occurred in parts of the Highlands. The spread of lawlessness has tended to follow larger patterns of development. Hence the concentration of organised crime in the expanding urban centres, armed hold-ups along the arterial highways, and inter-group conflict in the vicinity of large-scale resource development projects. The incidence of corruption, fraud and 'white-collar' crime has also increased significantly in recent years.

Quantifying the extent of these problems is difficult given the paucity and partial coverage of available statistics. Criminal justice data is largely confined to the urban areas, where less than $15 \%$ of the total population live. They nevertheless suggest a marked growth in crime, with a $65 \%$ increase in the number of serious offences reported to the police over the last decade. ${ }^{6}$ Port Moresby, the national capital, accounts for $40 \%$ of all reported serious crimes. Mount Hagen (Western Highlands) and Lae (Morobe) rank second and third respectively. With a conservatively estimated population of over $313,000,{ }^{7}$ Port Moresby has been described as one of the most dangerous cities in the world. ${ }^{8}$ Between 1996 and 1998, the capital alone accounted 
for a recorded total of 232 murders; 3,361 robberies; 2,131 break and enters; 556 cases of causing grievous bodily harm; 816 serious sexual assaults; 585 drug offences; and 307 cases of illegal use of firearms.'

Media and anecdotal accounts draw attention to the violent and predatory activities of raskol gangs. Although they tend to be concentrated in urban centres, criminal gangs are found in many rural areas as well. Sexual assaults against women and girls appear to be widespread, and are by no means confined to gangs. ${ }^{10}$ Gangs operate with relative impunity in the absence of effective deterrence from either the police or informal community controls. The typical probability of being arrested for crimes of larceny has been estimated recently at just over $3 \%{ }^{11}$ Contrary to their depiction in popular stereotypes, gangs are often well integrated into their local communities. As well as ties of kinship and personal association, raskols engage in selective acts of redistribution, providing material and other benefits to their neighbours in, often, the poorest and most socially deprived urban communities. ${ }^{12}$

At a macro level, urban raskolism has developed in an environment where access to legitimate economic opportunities is severely restricted. A recent survey estimated that $18 \%$ of the Port Moresby population rely on crime as their principal source of income. ${ }^{13}$ Raskolism has become, in effect, the largest occupational category in the informal urban economy. Rampant corruption among the political elite has also fuelled the rise of raskolism, providing a powerful rationalisation for street criminals. ${ }^{14}$ Falling commodity prices, deteriorating government services and infrastructure have contributed to rural poverty and the spread of raskolism from urban centres to rural areas. These developments, in turn, have placed enormous pressure on an already weak criminal justice system.

As well as the devastating impact on individual victims, concerns about lawlessness have undermined commercial and investor confidence. They have become major constraints to the achievement of national and local development objectives. Employers in PNG recently ranked theft and crime, followed by corruption and then poor infrastructure, as the most significant obstacles to doing business. ${ }^{15} \mathrm{~A}$ reinforcing downward spiral has developed whereby rising crime reduces legitimate economic activities which, in turn, leads to further crime and so on.

Many of the issues underlying PNG's current problems are shared with other developing and newly democratising countries. They include a potent cocktail of local and global factors contributing to uneven development and growing levels of division, exclusion and poverty. While domestic policymakers and international donors scramble for practical and timely solutions, it is clear that there are no quick fixes.

\section{FORMAL AND INFORMAL JUSTICE SECTORS}

The encounter between different traditions of justice brought about by colonialism in Melanesia, as elsewhere, generated many new tensions. It also gave rise to new synergies and the possibility for creative interaction between different regulatory traditions. Ideas and practices of law and justice relate to particular social and political 
orders. In western societies, the legal system provides the official framework for the regulation of relations between citizens, corporate entities and the state. In practice, many subordinate regulatory systems operate alongside, and interact with, this formal system. ${ }^{16}$ The state is nevertheless central to understandings, structures and processes of law and justice in such a polity. In the case of crime, for example, it is the state that defines the categories of prohibited behaviour, prosecutes those who allegedly engage in them, and administers punishment to those who are found guilty.

In 'traditional' Melanesia, perceptions and practices of justice reflected the social and political organisation of small, essentially 'stateless', societies. Rather than being centralised in a single entity, authority was typically dispersed throughout the social body. 'Law' was an indivisible part of social and political life in these societies. Kinship and social relations were fundamental to the determination of an individual's rights and obligations in respect of others. There was no concept of 'crime' per se. Disputes were defined and resolved within an elaborate framework of kinship, status and relationships. ${ }^{17}$ Notions of reciprocity and equivalence were also central to the redress of perceived wrongs, as they were to other social activities. Given that parties to a dispute were likely to continue to live in close proximity and interdependence, an important objective of dispute settlement was the restoration of relations between them. Compensation or the exchange of gifts was a common form of redress and was generally the result of protracted negotiation and mediation between the parties and their respective kin networks. Principles of restorative justice were thus central to the settlement of disputes between members of a recognised group or community. Where, on the other hand, there was no morally binding relationship between the parties, as with strangers or members of rival groups, retribution or 'payback' was a more likely response.

Interactions between western law and justice institutions and Melanesian processes of self-regulation provide insight into the challenges currently facing the formal legal system in PNG. They also reveal important areas of continuity in indigenous responses to conflict and wrongdoing and these, in turn, provide lessons for law and justice reform today. The formal system is largely a legacy of the period of institutional modernisation that preceded Independence. Throughout most of the colonial era there was in fact no discrete system of judicial administration applying to indigenous subjects. Instead, the policing, judicial and penal powers of government were part of an undifferentiated and decentralised system of 'native administration'. This system was personified in the Australian district officer - the kiap — who acted simultaneously as administrator, policeman, magistrate and gaoler at local levels. A special set of regulations (the Native Regulations), applying exclusively to Melanesians, was administered in separate courts presided over by the kiaps.

'Custom' was never officially accorded the status of law and no attempt was made to incorporate customary institutions into the formal government system. At the same time, 'traditional' structures were only interfered with when perceived as a threat to colonial authority or European prestige ${ }^{18}$ and continued to shape the daily existence of most Melanesians. The evolutionary premise of the colonial 'civilising mission' was 
that the indigenous population would remain subject to their 'traditional' practices until such time as they had 'advanced' sufficiently to be fully integrated into the 'modern' legal system. ${ }^{19}$ Integral to colonial thinking was the assumption that there was nothing in indigenous methods of governance that could provide the basis for a uniform system of justice. Linked to this was the belief that 'custom' would eventually die out under the impact of 'civilisation' or, in a later phase, 'modernisation'.

While some district officials argued for the recognition of indigenous regulatory processes ${ }^{20}$ opposition was expressed by the long serving Australian Minister for Territories, Paul Hasluck (1951-1963). Hasluck, the principal architect of modernisation, was intent on building a system of justice consistent with what he saw as the future political needs of the Territory. ${ }^{21}$ This entailed the gradual replacement of the discriminatory system of 'native administration' by a modern system of centralised government, which, in turn, would provide the institutional foundations for eventual statehood. ${ }^{22}$ While kiap justice was a pragmatic strategy for the gradual expansion and consolidation of administrative influence, it was not seen as an appropriate option for the long-term governance of the Territory. Establishing a centralised judicial system administering a uniform body of law was, in Hasluck's view, a necessary condition for the self-government that would one day follow. The adoption of an essentially Anglo-Australian model of law and justice was proposed in a review of the system of judicial administration commissioned by Hasluck, the socalled Derham Report of $1960 .^{23}$

Ironically, while official thinking maintained that indigenous institutions were inadequate to the task, the colonial administration was dependent on them in practice for the maintenance of peace in most rural areas. ${ }^{24} \mathrm{~A}$ high level of cooperation and interdependence developed between many kiaps, Melanesian policemen and 'traditional' leaders, including unofficial village 'magistrates', at local levels. ${ }^{25} \mathrm{Had}$ official thinking been more receptive it would certainly have been possible to develop a framework combining elements of both introduced and indigenous systems.

Such a possibility was out of the question, however, because it "was in fundamental conflict with the official political goals and therefore restricted to an underground existence." ${ }^{26}$ The growing emphasis on nation-building that emerged during this period served simultaneously to draw attention away from the role of indigenous structures of governance, including mechanisms for dealing with conflict. The subordination of local institutions within the larger nation-building project has prevailed throughout the post-Independence period and conforms to a broader pattern of neglect evident in other Melanesian countries. ${ }^{27}$

For many observers, the decision to establish a modern centralised system contributed to the erosion of local social controls and the subsequent growth of PNG's 'law and order' problems. ${ }^{28}$ While there have been many other factors at work, there is little doubt about the weakening of local regulatory systems. Related to this is the marked failure of the modern system to facilitate the mutually supportive interactions that developed in practice between kiap and indigenous ways of doing 
justice. While the Australian kiap may not always have been aware of the extent and character of these engagements, they were generally conducive to the maintenance of peace at local levels.

Contributing to the relative success of the kiap system in dealing with disputes was the large repertoire of agency functions and powers that these officials could draw upon. ${ }^{29}$ These extended well beyond their official magisterial powers. The kiap also had considerable discretion in the exercise of his powers. He could, for example, link dispute resolution to the provision or withdrawal of various government services and facilities. He could persuade and reward, as well as punish. He could address remedies to either individuals or groups. Kiap justice accorded more closely with indigenous practices because it approached dispute resolution in a more holistic way than was possible under formal western juridical practice. In doing so, it produced outcomes that were generally acceptable in local terms. There are important continuities between kiap justice, particularly its holistic and problem solving approach, and many of the informal restorative justice practices that have emerged in Papua New Guinea since Independence.

Kiap justice's capacity to negotiate the seemingly unbridgeable space between the requirements of colonial order and indigenous perceptions of justice provides an illustration of what Sally Falk Moore has described as a "semi-autonomous social field":

The semi-autonomous social field has rule-making capacities, and the means to induce or coerce compliance; but it is simultaneously set in a larger social matrix that can, and does, affect and invade it, sometimes at the invitation of persons inside it, sometimes at its own instance. ${ }^{30}$

In practice, if not necessarily by design, kiap justice allowed for a high degree of articulation between formal and informal fields of justice that was, in turn, an important contributor to the administration's much-lauded Pax Australiana. ${ }^{31}$

By contrast, the incremental processes of centralisation and specialisation that followed the endorsement of Derham's proposals served to close down or weaken many of the points of articulation between formal and informal systems that had contributed to peace. In the process, the differences between these regulatory systems became more apparent, as did the deficiencies of the formal system in the eyes of many local litigants. Thus the professional magistrate, who replaced the kiap, was constrained by all manner of substantive, evidential and procedural rules. Professional, as opposed to kiap justice, took much longer and entailed a cumbersome and formalistic process, all conducted in a foreign language. Professional officials, in the form of lawyers, magistrates, police officers and so on, now dominated proceedings, leaving little scope for meaningful participation by parties to the dispute and their wider support groups. Local litigants viewed this new system as exclusionary, confusing, and often profoundly unjust. ${ }^{32}$ Speaking of the Western Highlands, Marilyn Strathern noted that: 
The Kiap's handling of trouble cases in the past combined both a concern for public order and a capacity to deal with minor offences. In fact, these derived from different aspects of his roles (administrator and magistrate), but it meant that he "settled disputes" roughly along lines familiar to Hageners. The paradox is that although the modern official courts are ostensibly concerned with law and order, they fail in Hagener's eyes to take cognisance of matters directly related to both of these elements. ${ }^{33}$

Not surprisingly, dissatisfaction with the process and outcome of professional justice led to a return to older traditions of self-help in some areas. Many of these involved the use of violence as enhanced mobility created new opportunities for conflict. Socalled tribal fighting - a practice which had been effectively suppressed under the kiap system - reemerged in parts of the Highlands in the early 1970s. The availability of modern firearms provided an additional lethal ingredient.

Twenty-seven years after Independence, minor disputes in rural areas are still dealt with largely by informal means as they have adapted to changing circumstances. The formal law and justice sector remains geographically, as well as socially, distant for many villagers. It also suffers from chronic under-resourcing that has seriously affected its operations. Informal means vary in different places but are likely to include a combination of methods: negotiation or mediation by kin, 'traditional' leaders or church officials; village moots; or the decisions of local komitis. Village Courts are also used widely and constitute the most important hybrid institution established in the post-independence period (see below). The effectiveness of informal processes is largely a consequence of the degree of social cohesion of rural communities. Social and economic change has had a seriously corrosive effect in many places. A common complaint relates to the lack of respect shown to village leaders and customary authority, particularly by youngsters exposed to the urbanoriented education system and the hedonistic values of global culture. Likewise, alcohol abuse has weakened social cohesion in both rural and urban communities, becoming a major cause of violence against women and children. ${ }^{34}$

The formal system proclaims a monopoly over the processing of the most serious incidents of conflict and dispute. Its record in this regard, however, leaves much to be desired. It has proved particularly ineffectual in dealing with the large inter-group conflicts that have broken out periodically in parts of the Highlands. There is evidence in some rural areas of an increasingly destructive entanglement between the social control processes of state and local kin-based associations. Rather than leading to a strengthening of overlapping social fields, as in the case of kiap justice, this process ultimately weakens both and generates further conflict. This is most evident in cases where officials endowed with state powers use these powers for essentially 'private' or other 'unofficial' ends. This would include, for example, the case of a police officer using a police raid to punish an adversary in a marital dispute, ${ }^{35}$ or a Village Court magistrate responsible for maintaining peace and good order who is simultaneously a local fight leader. ${ }^{36}$ 
It is clear that many ordinary Papua New Guineans have little faith in either the efficiency or fairness of the formal justice system. There is a popular perception of a widening gap between 'law' and 'justice'. In addition to the brutality and violence of many police actions, there is a view that those with power and influence can manipulate the formal system to their own advantage. ${ }^{37}$ In this respect, the deficiencies of the present system relate as much to lack of legitimacy as to lack of institutional capacity.

At the policy level, the incessant debate about 'law and order' in Papua New Guinea has focused on the issue of declining state capacity. Restoring law and order has been portrayed as a challenge primarily for the state. Practical proposals have thus concentrated on strengthening the formal sector. Continuing a long tradition of neglect, the role of informal institutions has been seen as peripheral at best.

Donor assistance to the law and justice agencies has reinforced the centrality of the state in this respect. Most assistance continues to be in the form of capacity building within state institutions. The outstanding challenge today is to develop appropriate strategies for enhancing the capacity of both the formal and informal sectors and linkages between them.

\section{THE LAW AND JUSTICE AGENCIES}

\section{The Royal Papua New Guinea Constabulary}

The Royal Papua New Guinea Constabulary faces enormous challenges. The scale of existing problems of order and PNG's demanding topography would stretch any modern police force. In some areas the police have been literally outgunned by groups armed with automatic weapons. Many of the factors contributing to lawlessness are issues of development that go well beyond the realm of law enforcement. Expectations of the police are often unrealistically high. Lasting improvement in the performance of the constabulary requires changes in the wider environment and the mobilisation of a range of other stakeholders. There is a pressing need to overcome popular distrust of the police and to develop more cooperative and productive linkages with community and non-government organisations.

At Independence, police coverage extended to only $10 \%$ of the total land area and $40 \%$ of the population. ${ }^{38}$ Police resources are still concentrated in the towns and many rural areas are accessible only with considerable difficulty and expense. The size of the force has failed to match the demands of a growing population and escalating lawlessness. In 1975, when crime rates were relatively low, there were 4,100 police officers covering a national population of slightly more than 2 million people. At the end of 1998, with a total population of over 4.6 million and serious problems of order, there were still only 5,000 police officers, of which $20 \%$ were either reserves or auxiliary officers. ${ }^{39}$ Singapore, with a similar population, has more than double the number of police operating on a small island with excellent transport and communication infrastructure. ${ }^{40}$ 
Lack of adequate government support has been a major constraint. The bulk of spending in the annual budget goes on salaries and wages, which, according to some accounts, consume $80 \%$ of the total police budget. ${ }^{41}$ Funds for petrol, airfares, office equipment and other basic necessities are scarce and officers-in-charge are forced to seek external assistance, often from local business houses. The physical condition of many police stations and houses is appalling. Health authorities condemn police facilities regularly as unfit for human habitation. Barrack-type accommodation reinforces the separation between police and the surrounding community. While many dedicated officers struggle to maintain standards, poor working conditions have had a corrosive impact on morale and operational efficiency.

Disappointing performance in basic crime prevention, record keeping, investigation, and prosecution are, in part, a consequence of the shortage of experienced and specialist officers. ${ }^{42}$ It also reflects the constabulary's colonial origins as an institution whose primary role was the extension of government control and only secondarily the control of crime. Lack of adequate on-the-job supervision has also contributed to ill discipline. Allegations of serious human rights abuses against individuals and groups are commonplace. ${ }^{43}$

An internal affairs division is responsible for managing public complaints against the police. In practice, less than $15 \%$ of complaints are resolved and lengthy procedural delays are usual. ${ }^{44}$ Another disturbing trend in recent years has been the theft or disappearance of weapons from police armouries. Suspicions abound that unscrupulous officers have been selling or hiring weapons to criminal groups and those involved in inter-group conflicts.

Lack of capacity and poor community relations have contributed to the tendency to be confrontational in dealings with individual suspects and groups. The superficial 'strength' of reactive policing disguises the actual weakness of the institution. Reactive approaches have contributed to popular distrust and fear of the police. Police violence fuels criminal violence in a reinforcing spiral that becomes increasingly difficult to break. ${ }^{45}$ Violent encounters with the police have become part of the process of induction into raskolism. While there are now serious efforts to develop community policing, the concept itself remains unclear in the eyes of most people, including many officers. The 1984 Clifford Report remarked that many police saw it as "the police being close enough to control the community — or at least to instruct it how to behave" ${ }^{46}$ The same is true of many officers today, over sixteen years later, particularly in the Highlands. The dominance of this retributive approach in contemporary policing practice, with its continuous undermining of police/community relations, remains the most significant source of the constabulary's current weakness.

\section{Correctional Services}

The Correctional Service (CS) has been the most neglected of PNG's law and justice agencies. Low annual appropriations have been barely sufficient to cover wages and basic institutional costs. The condition of prison facilities and staff housing has 
deteriorated alarmingly over the years with predictable effects on the morale of staff and detainees. ${ }^{47}$

As a method of punishment, imprisonment elicits ambivalent views in the wider community, being seen as too harsh in some cases and too 'soft' in others. ${ }^{48}$ This ambivalence also signifies differences in approaches to wrongdoing between formal and informal systems of justice. Removing offenders from society and locking them up in isolated institutions fails to deal with many of the issues that are central to informal dispute settlement processes. There is, for example, no role for the community or the parties most directly affected by the wrongdoing. Many Papua New Guineans view imprisonment as a form of punishment for and by the state, one that does little to 'resolve' the infraction or dispute in question. As such, it does not preclude the application of additional informal sanctions, such as compensation.

In practice, imprisonment has also served to reinforce, rather than reduce, criminal commitment and organisation. Raskol affiliations thrive in the major prisons. ${ }^{49}$ As elsewhere, prisons provide a fertile environment for the building of criminal identity, the expansion of criminal networks and the transmission of new criminal skills. Just as policing is implicated in the generation of lawlessness, prisons have also contributed to the reproduction of criminality and violence in contemporary PNG.

Despite the 'correctional' tag, the primary role of prison is still viewed as being the provision of secure and punitive custody. Lack of resources, including trained personnel, has contributed to the neglect of rehabilitation programs. Activities that do take place - vocational training, spiritual counselling, and gardening - tend to be dependent on the voluntary participation of individuals and groups from the wider community. There are few follow-up activities or organised support programmes for released prisoners.

The CS operates as an integral component of the overall law and justice system. As the end-of-the-line agency, ${ }^{50}$ many of the problems it faces are a consequence of inefficiencies in other parts of the system. Currently, over one-third of the prison population comprises remandees awaiting trial. Delays in court proceedings have added greatly to the pressures on the prison system, as well as contributing indirectly to prison breakouts. Overcrowded institutions experience difficulties in feeding and providing uniforms for the growing number of detainees. Many remandees would be more appropriately dealt with in separate remand centres or on bail in the community. Likewise, many minor offenders could be diverted from prison through the provision of adequately supervised community-based sentences or by decriminalising many minor summary offences, such as defaulting on debts and minor thefts.

\section{The Law and the Courts}

The development of a 'home-grown' legal system was an important theme in PNG's rhetoric of decolonisation. It was envisaged that 'custom' or customary law would play a major role in the post-colonial legal order. Indeed, the new Constitution explicitly adopted 'custom' as part of the underlying law that was to be developed 
when no existing law was applicable. The National Goals and Directive Principles in the preamble to the Constitution expressly called for "development to take place primarily through the use of Papua New Guinean forms of social and political organisation". ${ }^{51}$ They also recognised the importance of community structures, calling for "traditional villages and communities to remain as viable units of Papua New Guinea society, and for active steps to be taken to improve their cultural, social, economic and ethical quality". ${ }^{52}$ The constitutional scheme was thus receptive to the development of a more holistic and restorative approach to crime control and conflict resolution, including a greater degree of community participation.

Under the direction of Bernard Narokobi the Law Reform Commission was an early advocate of greater integration between western and Melanesian legal traditions. A 1977 report argued that the formal justice system should take greater account of the role of community mechanisms for dealing with conflict. ${ }^{53}$ The same report called for wholesale law reform to narrow the perceived gap between the values governing indigenous communities and those embodied in the introduced criminal law.

Despite the idealism of the 1970s, there has been little practical progress towards fulfilling these aspirations. Few of the recommendations of the Law Reform Commission were implemented and, in recent years, the Commission has lacked adequate funds, effective leadership and political commitment. The slow pace of the development of the underlying law has been blamed on Parliament's failure to enact enabling legislation. This situation has been remedied recently with the enactment of the Underlying Law Act 2000. ${ }^{54}$ Others have criticised the constitutional scheme, pointing to the non-justiciable character of the National Goals and Directive Principles, the wholesale adoption of pre-independence laws, and the subordinate role of the underlying law in the constitutional scheme. ${ }^{55}$

The superior courts - the supreme and national courts - are occasionally lauded as one of the success stories of the post-independence period. There are growing signs, however, that the generic problems affecting other state institutions are having an impact at even the highest judicial levels. An expanding caseload has placed great pressure on the court system and led to lengthy delays in proceedings. The present Chief Justice, Sir Arnold Amet, complained recently that "the judicial system is swamped" and recommended the development of alternative dispute resolution mechanisms. ${ }^{56}$ Finding suitably qualified citizens to sit as judges has long been a problem and there is a growing reluctance to recruit overseas candidates. A recent survey by the Institute for National Affairs (INA) found great concern among business executives about the declining predictability of judicial decision-making. ${ }^{57}$

These difficulties have been even more marked for the magistrates and staff of the subordinate courts who process the bulk of formal court cases. There are currently 130 District Court $^{58}$ magistrates. This works out at only 1 magistrate per 36,5000 people and less than 1.5 per administrative district. ${ }^{59}$ The deteriorating condition of court buildings and staff accommodation has also had an adverse impact in many areas. 
The courts in the national judicial system have a range of non-custodial penalties available to them including, for example, probation, community work orders, and good behaviour bonds. A shortage of trained supervisory staff and other resources has inhibited their use in practice. The idea of probation was proposed initially after independence on the grounds that it was consistent with the spirit of the Constitution and older traditions of managing disputes in the community. The Probation Act was passed in 1979. The first operational probation service was established in 1981 by a local NGO, the Eastern Highlands Province Rehabilitation Committee. This initiative developed a strong community network and became the model for the development of a national service. ${ }^{60}$

Probation offices have now been established in every province, with the exception of Western Province. ${ }^{61}$ While the use of probation is gradually increasing, lack of capacity remains a major constraint. In practice, there is often only one operational officer available in each province to carry out a large number of tasks. ${ }^{62}$

The weak capacity of the probation service has also had an impact on the workings of the Criminal Law (Compensation) Act of 1991. For many years the courts have taken account of any customary compensation paid by an offender to his/her victim as a mitigating factor when determining the appropriate judicial penalty ${ }^{63}$ The 1991 Act goes a step further and empowers the national and district courts to make compensation orders in addition to other penalties imposed for an offence. ${ }^{64}$ In order to assist the courts to determine the appropriateness and amount of compensation, the Act requires the Chief Probation Officer to submit a means assessment report. The ability of the probation service to fulfil this requirement has been seriously affected by its resource problems. ${ }^{65}$

Arguably the most significant institutional innovation in the law and justice sector since independence has been the establishment of the village courts. The primary function of these courts is to "ensure peace and harmony", and endeavour to obtain "amicable settlement of disputes" and apply custom "as determined in accordance with the Native Customs (Recognition) Act of 1963" "Village courts are intended to provide an accessible forum for dealing with minor disputes and infractions and one that is responsive to the needs and expectations of local communities. They are presided over by village leaders appointed as village court magistrates after consultation with the people. While designed primarily for rural areas, these courts also operate in the urban centres. There are currently 1,082 village courts covering approximately $84 \%$ of the country. ${ }^{67}$

Responsibility for the payment of allowances to village court officials was transferred from the national government to provincial and local governments under the Organic Law on Provincial and Local Level Government 1995. Provincial and local level governments claim that when these functions were transferred, no actual funding was transferred with them. As a result, many village court officials have not been receiving their allowances. While some continue to work, others refuse to hear cases until they receive payment. ${ }^{68}$ 
District court magistrates are responsible for supervising the village courts but in practice rarely have the capacity to do so. It is not realistic to expect 130 district court magistrates to supervise the work of 1,082 village courts. At the same time, supervision is clearly required. There have been many instances of village courts exceeding their powers under the Village Courts Act by, for example, hearing cases that should be tried before the formal courts, or by unlawfully sentencing offenders to imprisonment.

Many early observers complained about the formalism creeping into village court procedures. ${ }^{69}$ Illustrations included the construction of separate bush material courthouses and the holding of regular court sittings. Others, however, point to the successful synthesis between different traditions represented by these courts and their overall flexibility. ${ }^{70}$ The formalism that worries some observers may be more a reflection of local expectations and the practice of 'forum shopping' than a deliberate attempt by village magistrates to slavishly imitate the formal courts. Many villagers simply expect these courts to be more formal than the informal local forums that they operate alongside.

A common criticism of the village courts, particularly in the Highlands, is that they reinforce the subordination of women and children. ${ }^{71}$ There have been reports of women accused of adultery being imprisoned while their male partners go unpunished. Likewise, children have been locked up for minor offences. The problem here is that the courts have become too responsive to local power structures dominated by older men. In the process, they have compounded the grievances of the weakest groups in the community, notably women and children. The solution lies in a combination of better training that will discourage such inequitable outcomes and an effective system of supervision that will provide remedies to aggrieved parties. It is the weakness of the linkage between these courts and the formal system that is the source of many of their problems. Their strength lies in the provision of an accessible legal forum that is highly responsive to local expectations. Their location between the national court system and local dispute resolution mechanisms makes them an important point for creative interaction between formal and informal justice sectors. With appropriate support and supervision, these courts can provide 'semiautonomous social fields' that are capable of integrating different regulatory regimes at local levels, like kiap justice in an earlier era.

\section{DIRECTIONS FOR REFORM}

There have been numerous reports and reviews about law and justice issues in PNG over the years. As mentioned previously, the practical response of governments has been the adoption of short-term measures aimed at suppressing lawlessness in particular areas. These have entailed a familiar repertoire of curfews, liquor bans, and special policing operations.

The well-known weakness of the PNG policy-making environment ${ }^{72}$ has been accentuated by the sheer number of institutions and agencies comprising the law and justice sector. Separate departments and ministers exist for justice, the police and the 
correctional service. Each minister exercises a high degree of autonomy and no formal mechanism exists for ensuring coordination or even regular consultation between the various institutional components of the sector. In the absence of an overall sectoral vision and strategy, each agency has been able to develop their corporate plans and programmes independently of each other. Frequent changes in ministers, agency heads, and senior departmental officials have undermined further policy coherence in the sector.

\section{The National Law and Justice Policy and Plan of Action 2000}

Although policy instability continues to pose a major challenge, a window of opportunity presented itself with the election of the reformist Morauta government in 1999. The new government committed itself to an ambitious reform programme as part of its strategy to restore the integrity of state institutions and improve overall government sector performance. Establishing a secure and peaceful environment was recognised as a fundamental condition for the pursuit of other social and economic goals. A small working group of senior law and justice officials was tasked with preparing a draft national policy for the sector. Earlier proposals were reviewed, including the 1993 policy, and extensive consultations took place with a range of stakeholders. The Morauta cabinet endorsed the new policy and plan of action on 21 st August 2000. The policy provides the vision statement for the sector as a whole, while the plan of action consists of a detailed set of proposals for achieving this vision. ${ }^{73}$ These proposals are organised around three main pillars.

\section{(a) Improving the Efficiency of the Deterrence System}

The first pillar emphasises the need to improve the efficiency of the formal criminal justice system and is consistent with ongoing and proposed institutional capacity building activities. Australia has been funding development projects in the law and justice sector since the late 1980s. While initial assistance focused on the police, capacity building projects are now being provided to the Ombudsman Commission, the National Judicial Staff Service, the Legal Training Institute and the Attorney General's Department.

The new policy recognises that the state has a vital role to play in the maintenance of peace and good order and that its agencies must be appropriately equipped in terms of human and material resources. The strengthening measures proposed in the policy, however, are directed to the sector as a whole, rather than to individual agencies. These include strategies to revitalise the juvenile justice system and the Law Reform Commission, as well as the development of a national rehabilitation policy and multiagency approaches to tackling corruption.

Increasing community participation in law and justice processes lies at the heart of the new policy and is seen as an integral part of institutional strengthening. Emphasis is placed on the building of mutually reinforcing linkages between state and non-state entities around activities aimed at preventing or resolving conflict in a variety of social and institutional contexts. 


\section{(b) Coordination}

The second pillar relates to the critical issue of sectoral coordination. This is premised partly on the high level of inter dependence between criminal justice agencies in practice. Coordination between agencies is essential for ensuring that they operate effectively as an integrated system. As well as horizontal coordination, there is a need for vertical coordination between agencies and non-government actors operating at different social and geographical levels. The Organic Law on Provincial and Local Level Government, which is currently only partially implemented, mandates a major redistribution of functions and responsibilities from national to provincial, district and local level authorities. This larger exercise in decentralisation provides the broad framework for implementing the policy's vision of devolved law and justice and increased community participation.

At the national level, the policy recommends the establishment of a National Coordination Authority comprising the chief executives of the law and justice agencies, related government departments and co-opted members. This body will be responsible for the monitoring and review of sectoral policy, planning and budgeting, and the coordination of law and justice data and research. It will also provide oversight of sectoral training, liaison with other stakeholders at the national level, and cross-sectoral issues. Provincial level coordination will be based on the existing Provincial Peace and Good Order Committees. In addition to representatives from the law and justice agencies and provincial authorities, these committees will include a representative group of non-government stakeholders. Their functions will be broadly similar to those of the national authority. They will also serve as a conduit for the flow of information between national and local levels.

District level authorities are proposed to assist in the coordination of law and justice services in conjunction with local level governments. They will be involved in identifying and responding to local law and justice priorities, allocating resources, and the coordination of programs such as community policing, community based corrections and local preventive and restorative justice initiatives. At the time of writing, a number of 'community justice centre' pilot projects are being designed and these will be used to test and refine suitable local-level mechanisms. It is recognised that these mechanisms need to be sufficiently adaptable to accommodate different local circumstances.

\section{(c) Prevention and Restorative Justice}

The third pillar of the new policy relates to crime prevention and restorative justice. It seeks to strengthen the capacity of informal community based and other nongovernment structures to prevent and resolve conflict at local levels. 'Restorative justice' is the term used to describe the broad criminal justice reform movement that has emerged in many countries in recent years. It is often contrasted, somewhat simplistically, with retributive justice whose principal rationale is the deterrence of wrongdoing through punishment. While most modern criminal justice systems combine retributive and restorative principles in practice, it is their organisation 
around processes of identifying and punishing individual offenders that is used to distinguish them from restorative alternatives. Hence the traditional focus of the criminal process on apprehending suspects (the role of the police), ascertaining their responsibility under the law (the role of the courts) and, if found guilty, the administration of punishment (the role of the correctional service). There is usually little scope for the participation of either the immediate victim(s) of the wrongdoing or the wider community in this process.

By contrast, restorative justice provides a major role for the community and those who have been most directly affected by an offence or dispute. Ironically, the restorative justice movement in countries like Australia, New Zealand, Canada and the United States draws inspiration from the dispute resolution methods of indigenous, small-scale societies. An important objective of dispute resolution is seen as the restoration of balance and harmony in the community affected and, wherever possible, the healing of relationships damaged by wrongdoing or conflict. This involves allowing an offender to make amends for his/her infraction and, thereafter, to be reintegrated back into the community. Violence and other forms of wrongdoing are understood as doing damage to the fabric of a community and restorative practices are necessary to accomplish the necessary repairs. This is where law and justice activities have the potential for intersecting with other community building objectives. Empowering communities to manage conflict in this way can thus become an important force for community development.

Clearly not all conflicts or infractions are suitable for, or amenable to, restorative techniques. Retributive justice will always remain an option for dealing with the most dangerous and intractable offenders. In addition, where there are significant imbalances in power between particular groups, as in the case of women appearing before village courts, 'restoring' relations may simply serve to reinforce these underlying inequities. In such a case, a form of justice is needed that contributes actively to the transformation of the imbalances (e.g. 'transformative' justice). For the vast majority of minor offences and disputes, however, there remains enormous potential for developing restorative solutions that avoid the amplifying outcomes of retributive practice. Restorative justice in this broad sense is not a new idea in Papua New Guinea. As we have seen, practices like compensation, shaming and reconciliation have strong social foundations in Melanesian communities.

There are many examples of restorative justice institutions and practices in PNG today. Some of these operate independently of the state and are, in part, responses to the perceived failings or absence of state solutions. Others involve linkages or partnerships between state and non-state entities. As most of these practices are informal and occur in rural areas, they are often invisible to the planners and officials based in the central government offices in Port Moresby or in provincial headquarters. At the same time, they provide a rich reservoir of experience and innovation with much to offer the current reform process.

Mass surrenders and gang retreats are a fascinating illustration of an incipient restorative practice that has been developed in recent years. ${ }^{74}$ In the case of the 
former, groups of self-professed criminals surrender themselves and their weapons at public ceremonies. Surrendering groups ask forgiveness for their criminal deeds and assistance for their rehabilitation strategies. Surrenders are often brokered by church groups or individual pastors. Brokers are instrumental in persuading the group to renounce crime and, in return, offer help in securing access to legitimate economic or educational opportunities. The violence involved in a life of crime is often given as a reason for surrendering. Where court proceedings eventuate, magistrates are likely to take the fact of surrender into account. Business houses and others in positions to help are often sympathetic to the plight of such 'reformed criminals'.

Gang retreats bring criminals together with state officials, business and political leaders. As in the case of surrenders, church representatives often broker retreats. Criminals engage in frank discussions with those in positions of authority and influence, outlining their grievances and identifying what is required to get them to abandon crime. Like the surrender, the outcome of a retreat can be a commitment to leave crime in return for access to legitimate opportunities. Unlike criminal justice practice, these informal institutions are potentially restorative with the capacity for breaking the reinforcing pattern of retributive violence between raskols and police. They also offer the prospect of sustainable solutions by linking exit from crime explicitly to employment, education, micro-credit and social development options.

In some areas voluntary associations have been formed to assist in the rehabilitation of ex-prisoners and ex-criminals. For example, in 1984 a group of former prisoners set up the Western Highlands Ex-Criminal Self Help Task Force. This group continues to operate today, producing a weekly programme on the local radio and engaging in a variety of spiritual, vocational and agricultural training programs for 'youth at risk' and released prisoners. The group also visits those in police custody and prison and provides informal representation for members of surrendering groups appearing in court.

Contrary to their depiction in current stereotypes as disorganised and lawless communities, many urban settlements have well-developed capacities for selfpolicing. John Ivoro, a leader in Port Moresby's Saraga settlement, documents the successful mediation of disputes by a local dispute settlement committee in a large multi-cultural urban community. ${ }^{75} \mathrm{He}$ also tells the story of a mutually beneficial partnership forged between the committee and a neighbouring private company. The company approached the committee over their concerns about thefts and break-ins at the company premises. After listening to community representatives, the company agreed to engage local youth in casual employment as security guards and provide sponsorship to church and sporting activities. As a result, criminal activities diminished and a relationship previously based on distrust and hostility was transformed.

Members of the Saraga dispute settlement committee received their mediation training from the Peace Foundation Melanesia, an NGO that has been helping local communities deal with conflict since the mid-1990s. ${ }^{76}$ The Foundation offers training modules in people skills, conflict resolution, community development planning, 
training of trainers, and mediation and restorative justice. These modules have been developed with the full participation of villagers from many different parts of the country and are all linked to the general goal of building community cohesion and promoting community development. In practice, they work through existing community structures and local churches. The Peace Foundation has also worked with mining companies, the police, staff and detainees in prisons and university students. Training members of particular communities or institutions as trainers has given these initiatives a high degree of sustainability in practice.

While the Peace Foundation is probably the best-known NGO in this area, there are many others operating at local levels. East New Britain's Sosel Eksen Komiti is a good example. Initially established in 1986 as the Social Concern Committee of the East New Britain Provincial Assembly, they were incorporated as an NGO in 1991. Over the years, Sosel Eksen has built an extensive network of grassroots volunteers throughout rural East New Britain. Among its many programmes, it runs workshops and training courses directed at reducing drug and alcohol abuse, child abuse, and 'domestic' violence. There are approximately 120 trained extension volunteers living and working in villages throughout the province.

The peace process that has emerged out of the tragic conflict on Bougainville provides a rich source of restorative ideas and practices. While the conflict centred on the struggle between armed secessionists and the PNG security forces, it also served as a catalyst for many sub-conflicts between and within Bougainvillean communities. The collapse of state authority left the way open for the creation, and revival, of a host of local structures and processes of governance in different parts of the island. As such, it provides a unique opportunity for viewing the dynamics of order without state. The ongoing peace process has given rise to many innovative and culturally based strategies for reconciling the many different kinds of conflict provoked by the war. While subject to enormous variation, 'traditional' authority, in the form of chiefs, has played an important role in many areas:

It reduced the tensions that were often the driving force in violent localised conflict, including that between BRA and Resistance Forces. In some cases the roles of chiefs in promoting peace went much further. Some exerted control over local BRA or Resistance Forces, limiting them to defensive roles. Some played major parts in initiating reconciliation between groups in conflict, a role now increasing as the peace process gathers momentum. ${ }^{77}$

Women's groups, churches and NGO's have been active in reconciliation and rehabilitation activities with individuals, families, ex-combatants, and villages. The role of women in the current peace process recalls the long history (and longer prehistory) of women as peace-makers in Melanesia. ${ }^{78}$

The Peace Foundation has also been involved in the Bougainville peace process, working with chiefs, women's groups and others in the area of mediation, conflict resolution and restorative justice. ${ }^{79}$ John Tombot, a traditional chief and former village court magistrate in the Siwai district of southwest Bougainville, underwent 
training with the Foundation. Since 1997 he has been involved in over 300 mediations including many cases of homicide occurring during the conflict ${ }^{80} \mathrm{He}$ tells how many local people in his area believed the imposition of fines by the formal courts was primarily an income generating activity for magistrates. When the war broke out, many magistrates were openly attacked and disputes that had been dealt with by the courts were resumed, often with violent consequences. According to Tombot, restorative practices that accord closely with 'traditional' methods are much more successful than formal adjudication in achieving sustainable resolutions.

In other parts of Papua New Guinea, the lack of tangible support from distant headquarters in Port Moresby has also served to stimulate local officials into developing creative solutions. In one large provincial prison, the commander and his senior officers have gone to great lengths to build supportive relations with the surrounding community. A local NGO has been providing training courses for prison staff and their families, as well as detainees. Selected inmates have helped build and repair local community schools and perform various public works. The prison has been contracted by a local company to provide detainees for sign writing on vehicles. A nearby agricultural research centre has been allowed to use prison land and detainee labour to grow hybrid guavas. From being a depressingly insular institution concerned solely with security, this prison has become a hive of activity. Regular interactions have diminished fears and insecurities among the local community about the proximity of a large prison. Likewise, the morale of detainees, prison staff and their families has risen dramatically.

These are a selection of some of the restorative initiatives occurring in different parts of PNG. Many other examples could be cited. These practices have been developed under very different local circumstances and involve a range of both state and nonstate actors. The challenge now facing policy makers, law and justice practitioners and community and non-government sector leaders, is how to integrate these various practices within an overall regulatory system. It is the challenge of developing 'semiautonomous social fields' that allows the existence of complimentary layers of social regulation under the rule of law. These levels inevitably draw on different traditions and experiences but should ultimately be directed at achieving the same overall objective - the promotion of peace and good order. The new national policy contains specific recommendations aimed at 'community-building'. These involve the identification of particular community needs and priorities and the provision of appropriate training and other support designed to increase local capacities for selfregulation. The policy also introduces the notion of 'partnerships for peace' whereby support will be targeted at preventative and restorative initiatives between state and non-state entities. Wherever practical, support will be directed at these partnerships thereby building the capacities of formal and informal sectors simultaneously and, in the process, nurturing a process of mutual learning. 


\section{CONCLUSIONS}

It would be naïve to expect that law and justice reform alone could overcome PNG's problems of order. These problems are diverse and complex and need to be addressed in different ways. At the same time, fundamental reform is clearly needed. The formal justice system, particularly in its criminal justice role, has not only failed to stem lawlessness and conflict but has, in many ways, become a contributor to them.

At the heart of PNG's challenges of governance - including that of 'law and order' - lies the uneasy fit between the institutions and ideology of the modern 'nationstate' and the multiplicity of indigenous polities that constitute modern Papua New Guinea. The formal law and justice system is a relative newcomer and has been superimposed onto a patchwork of self-regulating local systems that have by no means 'disappeared' under the onslaught of modernity and externally induced change. On the contrary, the latter have been remarkably resilient and have engaged actively with institutions of more recent origin. Although many of these interactions are consistent with building a larger and sustainable social order, others are not.

While the role of the state internationally has undergone dramatic changes over the past two decades, its central role in national development is widely accepted. For many observers, PNG is a classic example of a 'weak state'. ${ }^{81}$ This weakness is manifested in the difficulties it experiences in carrying out the most basic tasks of statehood, including the maintenance of public order, preserving political stability, providing basic services, and managing the national economy. Building the capacity of state institutions, including the law and justice agencies, is a necessary response to this weakness. Problems arise, however, when the state is treated in isolation from its social environment. Lack of state capacity is often viewed as a 'technical' problem to be remedied by strategic inputs targeted exclusively at state institutions. The question of a state's relations to its wider society and the extent to which these might themselves be a source of its limited capacity is rarely raised. The fragile legitimacy of the state in Papua New Guinea has all too often been ignored in the haste to build its institutional structures.

An implicit argument in this paper is that the weak performance of PNG's formal law and justice system, particularly its criminal justice system, is as much an outcome of its lack of legitimacy, as it is a consequence of shortage of resources, 'technical' or otherwise. There are growing levels of distrust and disaffection with the workings of the formal system. This can be seen in the turning away from state remedies, the revival of older ways of dealing with conflict, as well as in the creation of new ones. Restoring faith in the law and justice system requires that priority be given to improving relations with the wider society it exists to serve. Building trust and confidence in the principal agencies is an integral part of any sustainable institutional strengthening activities. Community participation in law and justice processes is a necessary part of building the social foundations whose absence is a significant contributor to the sector's current weakness. 
While the weakness of the state is widely acknowledged, the weakness of PNG communities has received less attention. Building the conditions for sustainable peace and good order requires both a strong state and strong communities. Rapid social and economic change has taken its toll on even the most distant village. Combined with the deficiencies of formal processes, the erosion of community cohesion has meant a growing absence of effective conflict resolution capacities in many areas. Empowering communities to deal with local problems of order within an overall framework of national law is an important priority in the National Law and Justice Policy. As we have seen, there are already many community based organisations involved in conflict resolution and restorative justice initiatives in different parts of the country. Some of them already work with state officials and agencies, while others work with the private sector. Developing partnerships of this kind, as envisaged in the policy, is an important way of building the capacities of state and civil society simultaneously and in a mutually supportive way.

PNG's colonial and post-colonial history provides important lessons in the importance of developing law and justice strategies that can accommodate a degree of semi-autonomy at local levels within an overall national system of regulation. The relative success of kiap justice had less to do with the personal attributes of these agents of pacification, as with their ability to link the needs of colonial order with those of local power structures in a mutually reinforcing way. Their ability to approach disputes in a holistic manner allowed them to contribute to resolutions that were broadly acceptable and conducive to the maintenance of peace and good order. Local leaders were active participants in these processes, rather than merely passive bystanders. ${ }^{82}$ Kiap justice was thus able to integrate the requirements of an encompassing 'administrative' order with those of particular 'local' orders in a way that the post-independence justice system has singularly failed to do.

There are strong echoes of this holistic approach to conflict resolution in many of the restorative justice initiatives that have developed informally in PNG in recent years, often in response to the failings of the formal system. While restorative justice approaches elsewhere have attracted criticism for individualising responsibility for conflict, the novelty of these responses in PNG has been their deliberate attempt to address underlying causes, including the structural conditions that contribute to crime (e.g. by providing pathways back to legitimate economic activities). An important source of the weakness of the formal system has been its failure to address the broader issues of social justice that are widely seen as contributing to crime and conflict. Indeed, many Papua New Guineans view the formal system as reinforcing these grievances by, for example, punishing the minor criminals while leaving alone those who engage in serious abuse of public office. The ability of restorative responses to engage directly with social justice issues provides an important way of building the legitimacy of the law and justice system. Contrary to a negative perception of law and justice as being solely about control and suppression, restorative justice also provides a way of integrating law and justice processes with more positive and productive development activities. 


\section{ENDNOTES}

1 'Law and order' is the phrase that is used widely in PNG to refer to problems of criminal violence. Framed in this way, 'law and order' solutions generally entail emphasis on strengthening police capacity and punitive measures.

2 Examples include the imposition of curfews and the use of special policing operations.

3 This challenge is experienced, in varying degrees, in all the Melanesian countries, including Vanuatu and Solomon Islands.

4 GoPNG/UNDP. 1999. Papua New Guinea Human Development Report 1998 Hong Kong: UN at p 76.

5 Raskols is the term popularly used to describe members of criminal gangs. See, further, Harris, B.M. 1988. The Rise of Rascalism: Action and Reaction in the Evolution of Rascal Gangs. Discussion Paper 54. Port Moresby: Institute of Applied Social and Economic Research; Goddard, M. 1992. Big-Man, Thief: the Social Organization of Gangs in Port Moresby. Canberra Anthropology 15(1): 20-34 and Dinnen, S. 2001. Law and Order in a Weak State: Crime and Politics in Papua New Guinea. Honolulu: University of Hawai'i Press.

6 World Bank. 1999. Papua New Guinea - Improving Governance and Performance. Washington DC: World Bank at p 108.

7 See above, n 4 at p 175.

8 Zvekic, U. and Alvazzi del Frate, A. 1995. Criminal Victimization in the Developing World. New York: United Nations Interregional Crime and Justice Research Institute.

9 Sikani, R. 1999. Criminal Threat in Papua New Guinea. In Boeha, B. (ed.) AustraliaPapua New Guinea: Crime and the Bilateral Relationship. Port Moresby: National Research Institute at p 18.

10 Borrey, A. 2000. Sexual violence in perspective: the case of Papua New Guinea. In Dinnen, S. and Ley, A. (eds.) Reflections on Violence in Melanesia. Sydney: Hawkins Press and Asia Pacific Press.

11 Levantis, T. 1997. Urban employment in Papua New Guinea - it's criminal. Pacific Economic Bulletin 12(2): 73-84.

12 Dinnen, S. 2001. Above, n 5 at pp 76-77.

13 Dinnen, S. 2001. Above, n 5 at pp 76-77; Levantis, T. 1998. Tourism in Papua New Guinea. Pacific Economic Bulletin 13(1): 98-05.

14 Dinnen, S. 2001. Above, n 5 at p 1.

15 INA. 1999. Factors Contributing to the Lack of Investment in Papua New Guinea: A Private Sector Survey. Port Moresby: Institute for National Affairs at pp 14-15.

16 Moore, S. F. 1978. Law as Process: An Anthropological Approach. London: Routledge and Kegan Paul.

17 Epstein, A.L. 1974. Introduction. In Epstein, A.L. (ed.) Contention and Dispute: aspects of law and social control in Melanesia. Canberra: Australian National University Press at p 12.

18 The suppression of so-called tribal fighting is one example. The different ways in which sexual advances/assaults were dealt when a European (as opposed to an indigenous) woman was involved is another. 
19 Sack, P. 1989. Law, Custom and Good Government: The Derham Report in its Historical Context. In Latufeku, S. (ed.) Papua New Guinea: A Century of Colonial Impact 1884-1984. Port Moresby: The National Research Institute and the University of Papua New Guinea at pp 381-2.

20 Fenbury, D.M. 1978. Practice without Policy: Genesis of Local Government in Papua New Guinea. Canberra: Australian National University.

21 Hasluck, P. 1976. A Time for Building: Australian Administration in Papua New Guinea 1951-1963. Melbourne: Melbourne University Press.

22 Dinnen, S. 2001. Above n 5 at p 25.

23 Derham, D. P. 1960. Report on the System for the Administration of Justice in the Territory of Papua and New Guinea, Canberra: Department of Territories.

24 Downs, I. 1980. The Australian Trusteeship: Papua New Guinea 1945-75. Canberra: Government Publishing Service at p 150; Gordon, R. J. 1983. The Decline of the Kiapdom and the Resurgence of 'Tribal Fighting'. Oceania 53: 205-223 at p 211.

25 Kituai, A. I. 1998. My Gun, My Brother: The World of the Papua New Guinea Colonial Police, 1920-1960. Honolulu: University of Hawai'i Press.

26 Sack, P. 1989. Above, n 19 at p 382.

27 Liloqula, R. and Pollard, A. 2000. Understanding Conflict in Solomon Islands: A Practical Means to Peacemaking. State Society and Governance in Melanesia Project Discussion Paper 00/7 Canberra: Australian National University.

28 Gordon, R. J. and Meggitt, M. 1985. Law and Order in the New Guinea Highlands. Hanover, NH: University Press of New England.

29 Gordon, R.J. 1983. Above, n 24 at p 220.

30 Moore, S. F. 1973. Law and Social Change: the Semi-Autonomous Social Field as an Appropriate Subject of Study. Law and Society Review Summer 1973: 719-746 at p 720.

31 The establishment of peace, particularly among formerly belligerent groups in the New Guinea Highlands, was viewed as one of the most significant achievements of the Australian colonial administration.

32 Strathern, M. 1972. Official and Unofficial Courts: Legal Assumptions and Expectations in a Highlands Community Port Moresby: New Guinea Research Unit; Strathern, M. 1976. Crime and Corrections: The Place of Prisons in Papua New Guinea. Melanesian Law Journal 4(1): 67-93.

33 See above, n 32, Strathern, M. 1972 at p 143.

34 AusAID. 1997. Papua New Guinea Law and Justice Baseline Survey of Community Initiatives. Canberra: Australian Agency for International Development.

35 Standish, W. A. 1994. Papua New Guinea: The Search for Security in a Weak State. In Thompson, A. (ed.) Papua New Guinea: Issues for Australian Security Planners. Canberra: Australian Defence Studies Centre at p 72.

36 Reay, M. 1987. Laying Down the Law in Their Own Fashion. In Langness, L.L. and Hayes, T.E. (eds.) Anthropology in the High Valleys. Novato CA: Chandler \& Sharp at $\mathrm{p} 74$.

37 World Bank. 1999. Above, n 6 at p 110. 
38 Dorney, S. 1990. Papua New Guinea: People, Politics and History since 1975. Sydney: Random House at p 296.

39 Dorney, S. 1990. Above, n 38 at p 110.

40 Curtin, T. 1999. Project appraisal and human capital theory. Public sector reform in Papua New Guinea (unpublished seminar paper) Australian National University, Canberra as cited in Levantis, T. 2000. Crime catastrophe - reviewing Papua New Guinea's most serious social and economic problem Pacific Economic Bulletin 15(2): 130-142 at pp 139-140.

41 Taku, P. 1990. Royal Papua New Guinea Constabulary: Personnel and Policies (unpublished paper dated 4th December, 1990).

42 See, for example, "Lawman laments cases" Post-Courier 12th December 2000.

43 Dinnen, S. 2001. Above, n 5.

44 World Bank. 1999. Above, n 6 at p 10.

45 Dinnen, S. 2000. Breaking the Cycle of Violence: Crime and State in Papua New Guinea. In C. Banks (ed.) Developing Cultural Criminology: Theory and Practice in Papua New Guinea. Institute of Criminology Monograph Series No. 13 Sydney: Institute of Criminology.

46 Clifford, W., Morauta, L. and Stuart, B. 1984. Law and Order in Papua New Guinea (The Clifford Report) Port Moresby: Institute of National Affairs and Institute of Applied Social and Economic Research at p 119.

47 For example, "Judge says prison 'unfit for humans"” Post-Courier 6th November, 2000.

48 Strathern, M. 1976. Above, n 32.

49 Dinnen, S. 2001. Above, n 5 at p 107.

50 That is, the agency that comes in at the end of the criminal justice process after the police and courts have performed their role.

51 Constitution (PNG), s 1(6).

52 Constitution (PNG), s 5(4).

53 Law Reform Commission of PNG. 1977. The Role of Customary Law in the Legal System Report No. 7 Port Moresby: LRC, p 63.

54 No. 13 of 2000, certified on 18th August, 2000.

55 Weisbrot, D. 1982. The Impact of the Papua New Guinea Constitution on the Recognition and Application of Customary Law. In P. Sack (ed.) Pacific Constitutions. Canberra: Law Department, Research School of Social Sciences, Australian National University.

56 National 31st October, 2000.

57 INA. 1999. Above, n 15 at p 14.

58 The District Courts process summary offences and certain indictable offences. Decisions of the District Court can be appealed to the National Court presided over by a single judge.

59 This information is contained in a letter from the Secretary of the Department of Provincial and Local Government Affairs, Leo Meninga, dated 26th October, 2000.

60 Giddings, A. 1986. Some Alternatives to States of Emergency. In L. Morauta (ed.) Law and Order in a Changing Society Political and Social Change Monograph 6. Canberra: Research School of Pacific and Asian Studies, Australian National University. 
61 The Clifford Report. Above, n 46 at p 77.

62 These include advising courts on community sentences; supervising clients; preparing presentence and pre-parole reports; training and supervising volunteers; attending to administrative matters and liaising with communities. See Pitts, M. 2000 Informal Methods of Crime Control In Papua New Guinea. Unpublished MA thesis University of Newcastle, at p 96.

63 Dinnen, S. 1988. Sentencing, Custom and the Rule of Law in Papua New Guinea. Journal of Legal Pluralism and Unofficial Law 27: 19-54.

64 See, also, Newton Cain, T. elsewhere in this volume.

65 Banks, C. 1998. Custom in the Courts: Criminal Law (Compensation) Act of Papua New Guinea. British Journal of Criminology 38(2): 299-316 at p 313.

66 Village Court Act 1973.

67 Department of Attorney General. 1999. Brief to Minister for Justice, Hon. Kilroy K. Genia MP. pp 93-94.

68 A local newspaper recently reported an attack on the Eastern Highlands provincial administration offices by Village Court officials angry about unpaid allowances, some of which had allegedly been outstanding for 5 years. See National 15th December, 2000.

69 Paliwala, A. 1982. Law and Order in the Village: Papua New Guinea's village courts. In Sumner, C. (ed.) Crime, Justice and Underdevelopment. London: Heinemann.

70 Goddard, M. 2000. Three urban village courts in Papua New Guinea. In S. Dinnen and A. Ley (eds.) Reflections on Violence in Melanesia. Sydney: Hawkins Press and Asia Pacific Press at $\mathrm{p} 243$.

71 Garap, S. 2000. Struggles of women and girls - Simbu Province, Papua New Guinea. In Dinnen, S. and Ley, A. (eds.) Reflections on Violence in Melanesia. Sydney: Hawkins Press and Asia Pacific Press.

72 Regan, A.J. 1997. The Papua New Guinea policy-making environment as a window on the Sandline controversy. In Dinnen, S. May, R. and Regan, A. J. (eds.) Challenging the State: the Sandline Affair in Papua New Guinea. Canberra: Research School of Pacific and Asian Studies, Australian National University.

73 GoPNG. 1999. The National Law and Justice Policy and Plan of Action - Toward Restorative Justice 2000-2005. Waigani: Department of National Planning and Monitoring.

74 Dinnen, S. 1997. Restorative Justice in Papua New Guinea. International Journal of the Sociology of Law 25: 245-262; above, n 5 Dinnen, S. 2001.

75 Ivoro, J. 2000. Conflict Resolution in a Multi-Cultural Urban Settlement. Unpublished paper presented at the Conflict Management and Restorative Justice in the Pacific conference held at the University of the South Pacific, Port Vila, Vanuatu, June 2000.

76 Howley, P. 2001. Breaking Spears and Mending Hearts - Peace Foundation, Peace Makers, Custom Law and restorative Justice in Bougainville. Unpublished manuscript.

77 Regan, A.J. 2000. 'Traditional' leaders and conflict resolution in Bougainville: reforming the present by rewriting the past? In Dinnen, S. and Ley, A. (eds.) Reflections on Violence in Melanesia. Sydney: Hawkins Press and Asia Pacific Press at p 297. 
78 Rumsey, A. 2000. Women as peacemakers - a case from the Nebilyer Valley, Western Highlands, Papua New Guinea. In Dinnen, S. and Ley, A. (eds.) Reflections on Violence in Melanesia Sydney: Hawkins Press and Asia Pacific Press.

79 Howley, P. 2001. Above, n 76.

80 Tombot, J. 2000. Restorative Justice Bougainville Style - A Marriage of Custom and Introduced Skills. Unpublished paper presented at the Conflict Management and Restorative Justice in the Pacific conference at the University of the South Pacific, Port Vila, Vanuatu, June 2000.

81 Migdal, J.S. 1988. Strong Societies and Weak States: State-Society Relations and State Capabilities in the Third World. Princeton NJ: Princeton University Press.

82 Kituai, A.I. 1998. Above, n 25. 